\section{VOLTAGE REGULATION CONTROL USING BATTERY ENERGY STORAGE SYSTEM IN DISTRIBUTION NETWORK WITH HIGH PV PENETRATION STRENGTH}

Nur Muhammad Alif Ramli, Siti Maherah Hussin*, Dalila Mat Said, Norzanah Rosmin, Amirjan Nawabjan

School of Electrical Engineering, Engineering Faculty, Universiti Teknologi Malaysia, 81310 UTM Johor Bahru, Johor, Malaysia
Article history

Received

1 June 2021

Received in revised form 7 September 2021

Accepted

19 September 2021

Published Online

20 October 2021

${ }^{*}$ Corresponding author sitimaherah@utm.my

\section{Graphical abstract}

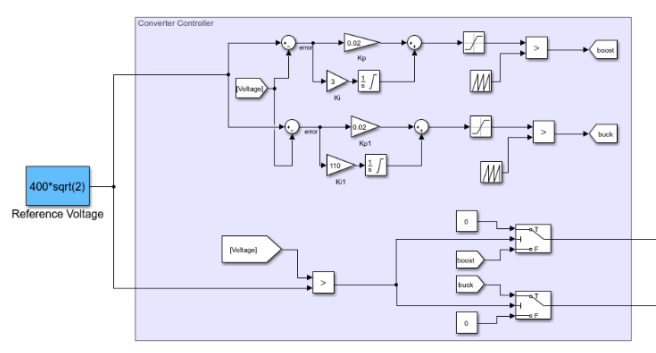

\begin{abstract}
In recent years, the increasing integration of PV generations into distribution network systems is becoming a huge concern as it introduces various complications such as voltage rise problems, especially during high PV penetration levels. Conventional mitigation methods using voltage regulating devices are not designed to mitigate this particular problem while emerging methods requires sacrifices in term of cost and profit to be made by PV system owners. Thus, mitigation using a battery energy storage system (BESS) is proposed in this paper, where it is specifically designed to solve the voltage rise problem in the distribution system during high PV penetration. This is achieved by controlling the charging and discharging of the BESS accordingly. To validate the effectiveness of the proposed BESS, a simulation using MATLAB/Simulink software of 25 distributed PV generations with respective loads connected to a distribution network power system is done. The penetration level is set from $0 \%$ to $100 \%$ and the voltage level is measured at the point of common coupling for each increment. The findings show that the BESS can regulate the voltage rise that occurred during high PV penetration of $80 \%$ and $100 \%$ from 1.11 p.u. and 1.13 p.u. to an acceptable voltage of 1.01 p.u.
\end{abstract}

Keywords: High PV penetration, BESS, voltage rise, distribution network, MATLAB

\begin{abstract}
Abstrak
Kebelakangan ini, peningkatan penyambungan PV ke dalam sistem rangkaian pengagihan menjadi tumpuan kerana ia menyebabkan pelbagai komplikasi seperti masalah voltan berlebihan terutama pada tahap penembusan PV yang tinggi. Kaedah konvensional menggunakan alat pengatur voltan tidak dapat mengatasi masalah ini kerana memerlukan pengorbanan dari segi kos dan keuntungan yang ditanggung oleh pemilik sistem PV. Oleh itu, penyelesaian menggunakan sistem penyimpanan tenaga bateri (BESS) dicadangkan dalam masalah ini, di mana ia dirancang khusus untuk menyelesaikan masalah voltan berlebihan dalam sistem pengagihan semasa penembusan PV yang tinggi. Ini dicapai dengan mengawal pengecasan dan pengenyahcasan BESS dengan sewajarnya. Bagi memastikan keberkesanan BESS yang dicadangkan, simulasi menggunakan perisian MATLAB / Simulink dengan mengambil kira
\end{abstract}


sebanyak 25unit sistem PV bersama dengan beban masing-masing disambungkan kepada sistem rangkaian agihan. Tahap penembusan PV ditetapkan dari $0 \%$ hingga $100 \%$ dan bacaan voltan diukur pada titik sambungan bagi setiap kenaikan voltan. Hasil kajian menunjukkan bahawa BESS dapat mengatur voltan berlebihan yang berlaku semasa penembusan PV yang tinggi iaitu $80 \%$ dan $100 \%$ daripada bacaan 1.11 p.u. dan 1.13 p.u. kepada tahap bacaan voltan yang diterima iaitu 1.01 p.u.

Kata kunci: Penembusan PV yang tinggi, BESS, voltan berlebihan, rangkaian agihan, MATLAB

(C) 2021 Penerbit UTM Press. All rights reserved

\subsection{INTRODUCTION}

The rising concern of high $\mathrm{PV}$ penetration can first be identified to be due to increasing solar PV installation throughout the world and how each year installation growth is most of the time larger than previous year [1 3]. Statistics from International Renewable Energy Agency (IRENA) [4] shows that the installed capacity increases significantly throughout the globe each year and that the yearly global addition if solar PV installation is having a spiking upward trend.

High PV penetrations level in distribution network causes many voltage and stability problems to distribution network system [5-7]. During the daytime, when PV systems are generating at assumed unity power factor and maximum power point (MPP) operation, negative impact will occur in the system. This results in temporary high voltage level at the distribution feeder. As PV penetration level increases, the voltage level increases which would lead to the voltage violation [8-10]. According to the Malaysian distribution code published by the Energy Commission, voltage should be regulated within $\pm 10 \%$ for medium voltage $(33 \mathrm{kV}, 11 \mathrm{kV}$, and $6.6 \mathrm{kV})$ distribution line, while $10 \%$ to $-6 \%$ for low voltage (400V and 230V) distribution line [11].

The penetration of PV into the low voltage (LV) grid has a negative impact on the operation of on load tap changers (OLTC) and automatic voltage regulation. Thus, to curtail the voltage rise issues, there is a need to incorporate communication between PV and voltage control devices. An energy storage system (ESS) is used to smooth of the PV generation in hourly basis as well as to reduce the operation frequency of the OLTC and SVR [13]. Moreover, it is also studied that in some cases, mitigation done by changing the tap position of the OLTC is not sufficient enough to reduce the voltage rise level and requires the voltage control support of the ESS [14].

Papers in [15-17] describe the active curtailment and reactive power compensation mitigation method for voltage problem in low-voltage (LV) distribution network. For these methods to work, the PV inverters are set to two limiting options. The first option is through limiting the amount of active power delivered to the network system and the second is to install an oversize inverter to create a compensation reserve. For active power curtailment, two strategies such as through fixing the maximum point of active power to say $70 \%$ or $80 \%$ or have control reduction of active power based on voltage level at point of coupling (PCC) can be done. Reactive power compensation method is done through the support from static reactive power reserve of the inverter. This additional reactive power flows will decrease the voltage level caused by distributed generations; however, the effectiveness is depending on the $R / X$ ratio of the system [18-20]. Both of these options obviously imply on the reduction of overall PV energy production and thus reduce the earning of $P V$ owners. This will affect the economic viability of $P V$ when the system will be generating less than what it was designed for while also results in green energy wastage. Other mitigation techniques for voltage rise problem are constant power factor control, adaptive droop-based supplementary control, DSTATCOM-Fuel Cell System, and emerging inverter control methods [21-24].

In this study, battery energy storage system is proposed to mitigate the voltage rise problem in the $400 \mathrm{~V}$ distribution network system with high PV penetration. The performance of the battery energy storage is evaluated by its ability to improve the bus voltage level in the distribution network.

Section 2 discusses on the modelling and simulation of BESS in distribution system while Section 3 describes the findings of the simulation. Finally, conclusion is made in Section 4.

\subsection{MODELING AND SIMULATION OF BESS IN DISTRIBUTION SYSTEM}

This section is divided into two subsections which are before and after implementing BESS in distribution network.

\subsection{Investigation of Voltage Rise Problem in Distribution Network System}

The first part of this study comprises the analysis done at the distribution system without any mitigation strategy as shown in Figure 1. The aim is to do an offline simulation of a simplified distribution system at different PV penetration level. 


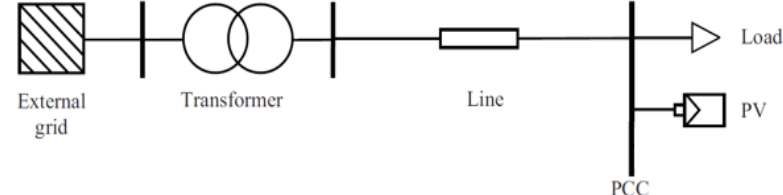

Figure 1 Single line diagram of distribution system

For the system design, a total of 25 loads with their owned respective PV generations will be integrated in the $400 \mathrm{~V}$ distribution network. To start the investigation of voltage rise occurrences due to high PV penetration, voltage sources are used to represent the PV systems working at peak generation of $20 \mathrm{~kW}$ respectively. Their respective load is $2 \mathrm{~kW}$ to represent low load condition. So, at a time, $18 \mathrm{~kW}$ power is injected into from each operating unit. This can essentially be translated that full penetration level of PV (100\%) for this particular distribution system to be 450 $\mathrm{kW}$. Theoretically, the voltage rise will happen in the system when the load on the network is at a minimum which will cause the distributed generation flow back to the source. The approximation of voltage rise can be calculated as shown in equation 1[25]. The variations of load condition as well as resistance and inductive reactance of the circuit are not covered in this study.

$$
\Delta V=\frac{P R+X Q}{V}
$$

where $P=$ active power output of the generator, $Q=$ reactive power output of the generator, $R=$ resistance of the circuit, $X=$ inductive reactance of the circuit and $V=$ nominal voltage of the circuit.

To simplify the simulation, all 25 units of load with PV system are set to have the same load and generation conditions at any time. Next, the voltage level of the bus at PCC at which the battery energy storage system is to be added later will be measured for a different PV penetration level of $20 \%, 40 \%, 60 \%, 80 \%$ and $100 \%$. The $\mathrm{PV}$ penetration term is defined as the percentage level of number of operating PV systems unit in a distribution network at any given time from total number of $\mathrm{PV}$ system connected to the system.

With these setups, a simplified distribution network as described is modelled as shown in Figure 2. 5 units of PV and load system are shown on the global simulation system while another 20 units are divided equally into 4 subsystems as shown in the red box in Figure 2 to avoid the simulation screen from being cluttered. The bus voltage (green scope) at PCC is taken from the first bus where the BESS is to be connected later.

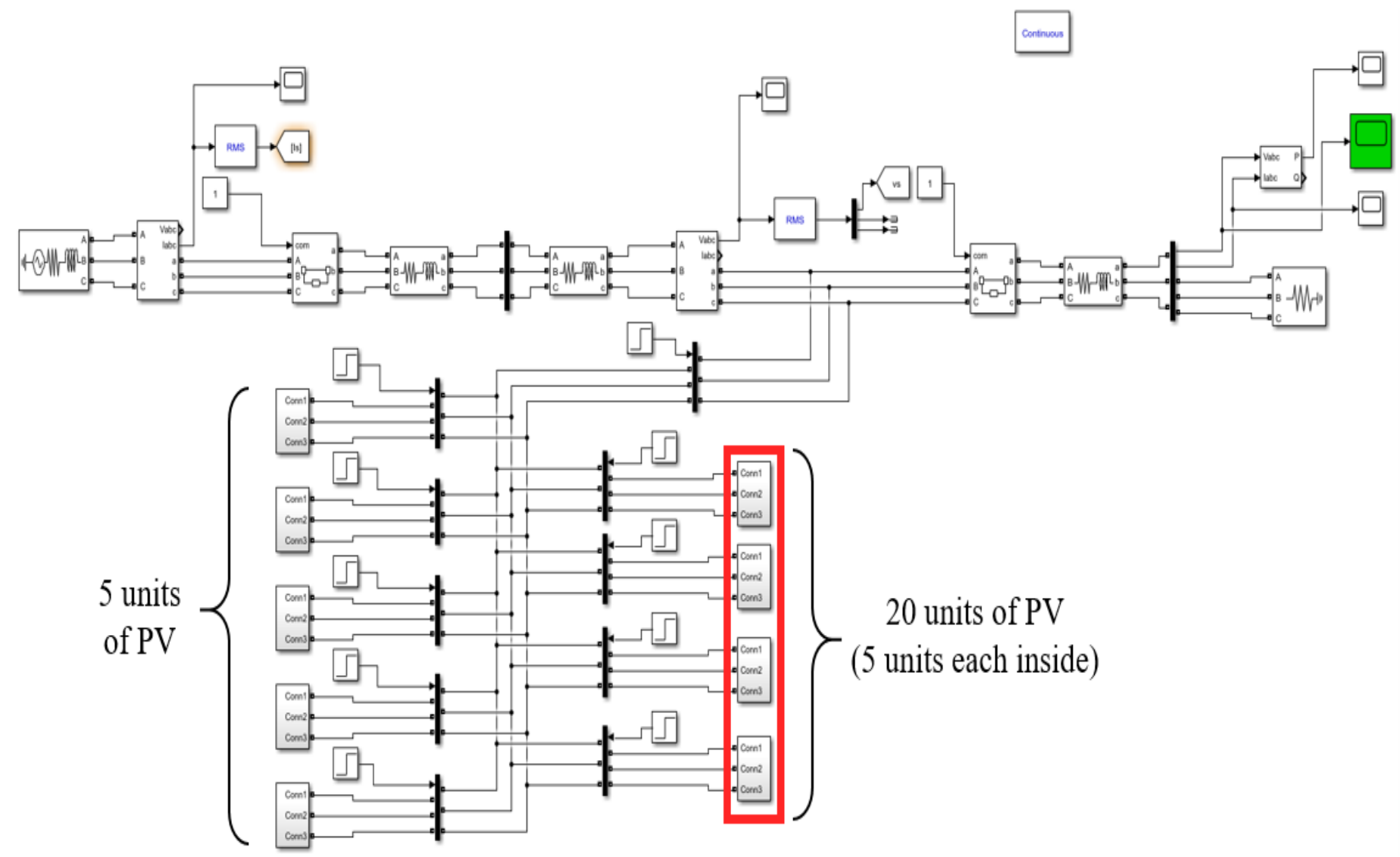

Figure 2 Modelling of the simplified distribution test system in MATLAB/Simulink without BESS 


\subsection{Voltage Rise Mitigation using BESS}

At this stage, a BESS is included for the voltage regulation of the system as shown in Figure 3 and Figure 4. Again, the simulation is done for the conditions in which maximum voltage rise occur which is during low load and peak PV generation.

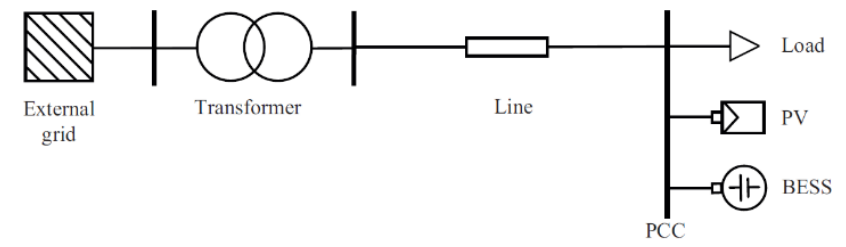

Figure 3 Single line diagram of distribution system of proposed mitigation

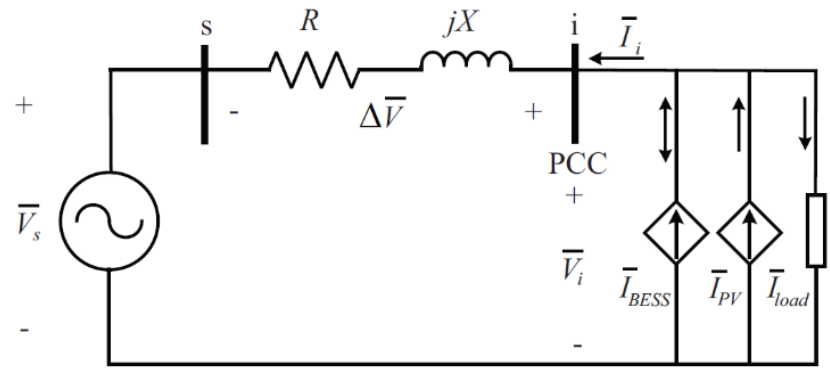

Figure 4 Equivalent model of the distribution test system

A 240V/100Ah Lead-Acid battery is connected to the distribution system through an uncontrolled full bridge inverter and a controlled bi-directional DC-DC buck-boost converter. The inverter converts the DC voltage to $\mathrm{AC}$ voltage for the connection to the distribution system while the converter converts bidirectionally from $400 \mathrm{Vrms}$ to $240 \mathrm{Vrms}$. The equivalent circuit of BESS is shown in Figure 5.

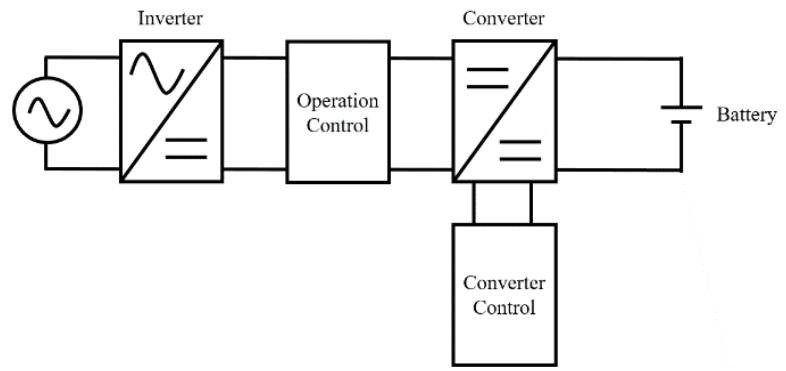

Figure 5 Equivalent circuit model of BESS

The voltage control flowchart is shown in Figure 6. Two control conditions are included in the flowchart, first being the state-of-charge (SOC) level of the battery and second being the voltage limit. The SOC level of the battery is set to typical $30 \%$ (SOCL) to $70 \%$ $\left(\mathrm{SOC}_{\mathrm{H}}\right)$ as safety precaution to avoid over charge or over discharge. The battery will only operate if the SOC level is within this range. Next condition is the voltage level at the measured bus. The voltage range is set to be 0.9 p.u. $\left(\mathrm{V}_{\mathrm{dc}-\mathrm{L}}\right)$ and 1.1 p.U. $\left(\mathrm{V}_{\mathrm{dc}-\mathrm{H}}\right)$. These two decisions will decide the mode of operation of the BESS with are "Stop", "Charge" and "Discharge" modes.

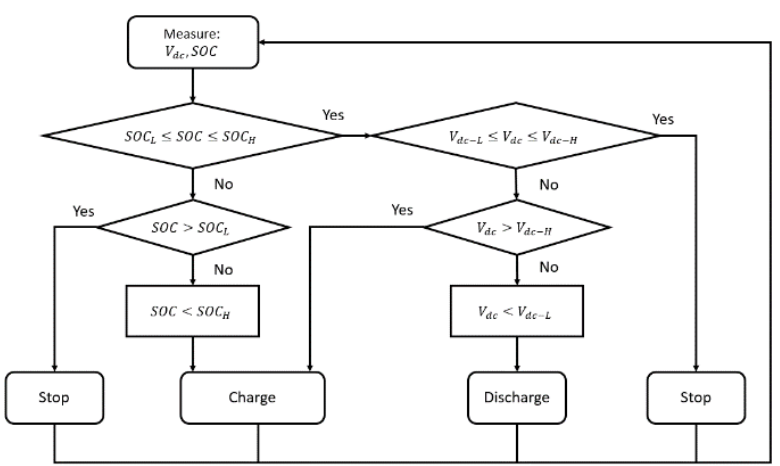

Figure 6 Flowchart of voltage control using battery energy storage system

With these, the simulation started with the modelling of separate BESS with $400 \mathrm{~V} / 240 \mathrm{~V}$ bidirectional DC-DC buck-boost converter as shown in Figure 7. A 240V and 100Ah lead-acid battery supply a typical suitable load of $100 \mathrm{Ohms}$ are used. In the design, some assumptions were made where all components are ideal and that the inductor current is continuous while the capacitors value is large enough to assume a constant voltage output.

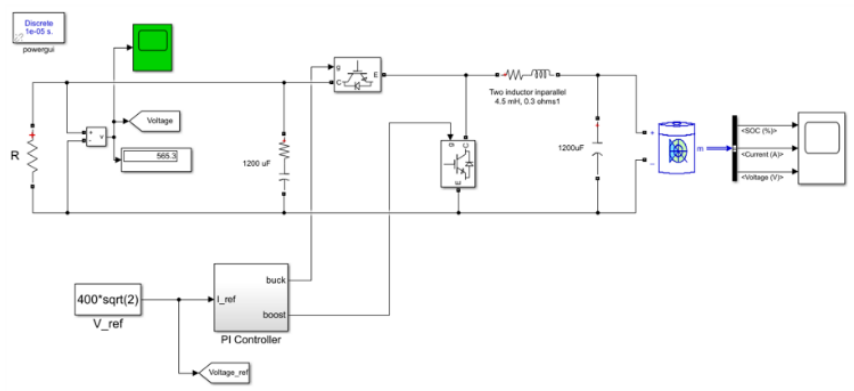

Figure 7 Modelling of bi-directional DC-DC buck-boost converter for 240V/100Ah Lead-Acid battery

Figure 8 shows the modelling of $\mathrm{PI}$ controller of the DC-DC buck-boost converter, where the voltage at $\mathrm{PCC}$ is compared to reference voltage of $400 \mathrm{~V}$. If the measured voltage at PCC is higher than the reference voltage the converter will operate in buck mode and start to charge the battery. If the measured voltage at $\mathrm{PCC}$ is lower than the reference voltage the converter will operate in boost mode and start to discharge the battery. The value of $K_{p}$ and $K_{i}$ are decided through trial-and-error method. From this, it is found that the value of $K_{p}$ and $K_{i}$ are 0.02 and 3 respectively for boost operation and 0.02 and 110 respectively for buck operation. 


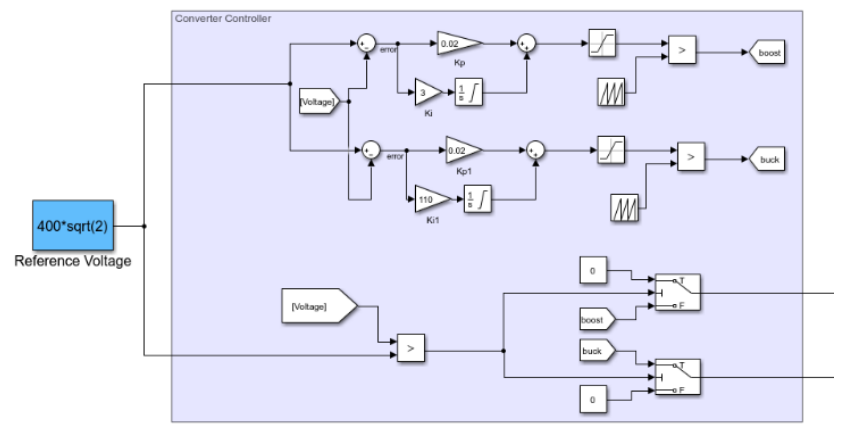

Figure 8 Modelling of converter control for buck and boost modes of operation

Figure 9 shows the model of operation control circuit comprises of switches and function blocks which translate the operation flowchart in Figure 6. Lastly
Figure 10 shows the modelling of combined of distribution system with BESS where BESS is connected at PCC operating at $400 \mathrm{~V}$.

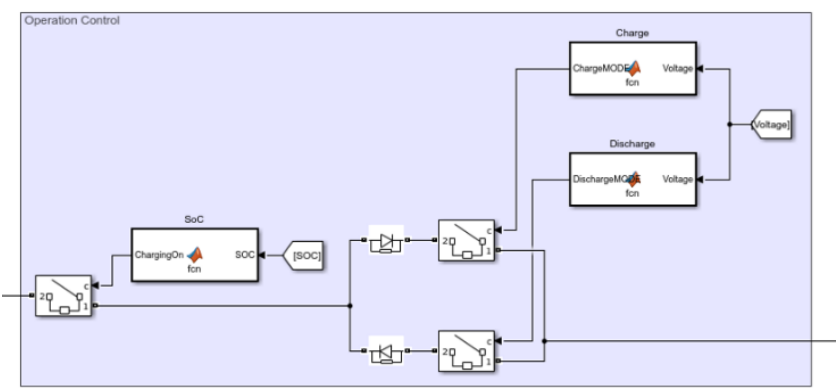

Figure 9 Modelling of Operation Control based on the operation flowchart

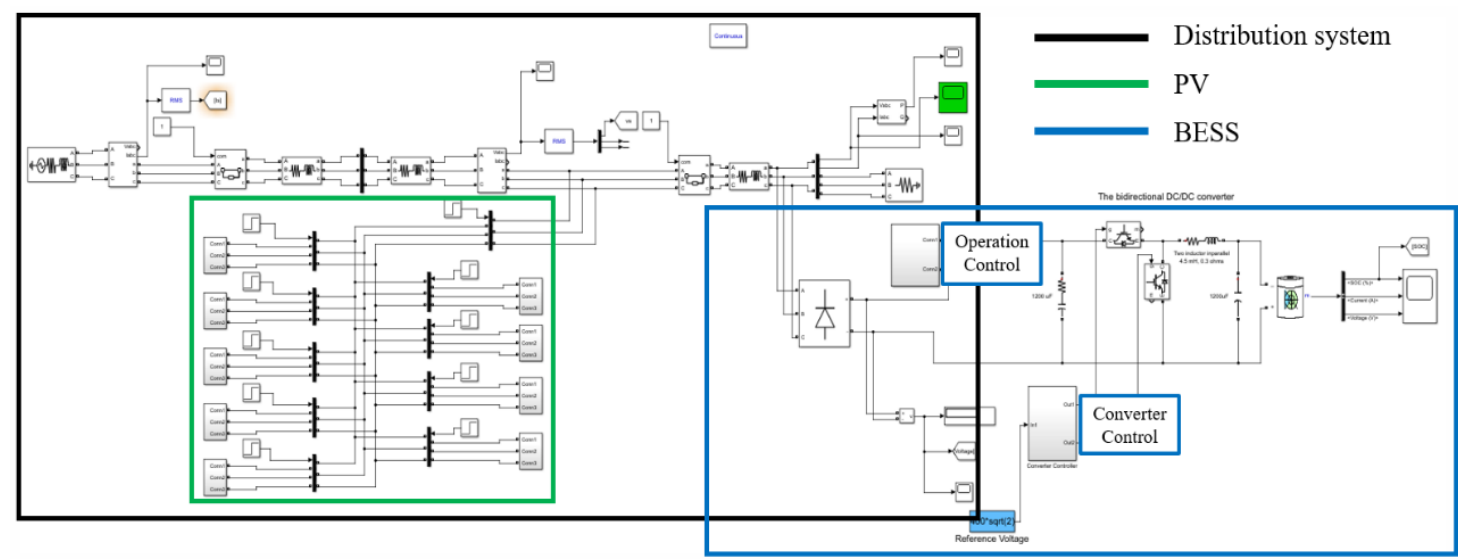

Figure 10 Combined system of BESS with previous distribution network system

\subsection{RESULTS AND DISCUSSION}

This section presents the simulation results and discussions starting with the investigation on voltage rise problem in the distribution network. The next part provides the results on the addition of BESS into the distribution system.

\subsection{Results of Voltage Rise Problem in the Tested Distribution System}

From Figure 11, it can be observed that during peak generation and low load condition, voltage level rises with PV penetration level. Using $400 \mathrm{~V}_{\text {rms }} V_{r m s}$ as base voltage referred at PCC, voltage levels in per unit are calculated from measurements. The increment of PV penetration is done after every $0.1 \mathrm{sec}$ to reduce the simulation run time and are labelled $\mathrm{T} 1, \mathrm{~T} 2, \mathrm{~T} 3, \mathrm{~T} 4$ and T5 for $0.5 \mathrm{~s}, 1.0 \mathrm{~s}, 1.5 \mathrm{~s}, 2.0 \mathrm{~s}$ and $2.5 \mathrm{~s}$ respectively.

At $20 \%$ and $40 \%$, the voltage level is within the range with 1.01 p.u. and 1.03 p.u. respectively. At $60 \%$
PV penetration level, the voltage level is 1.07 p.u. which is quite near to the voltage limit, 1.1 p.U. At PV penetration level of $80 \%$ and $100 \%$, the bus voltage level is 1.11 p.u. and 1.13 p.u. respectively and both are violating the voltage limit.



Figure 11 Bus voltage level at 20\%, 40\%, 60\%, 80\%, 100\% penetration with the 1.1 voltage rise limit (red dotted line) 
High PV penetration level is now identified as $80 \%$ and above. Table 1 summarizes the bus voltage before the implementation of BESS at different penetration level.

Table 1 Bus Voltages at 20\%, 40\%, 60\%, 80\%, 100\% PV Penetration

\begin{tabular}{ccc}
\hline Time & $\begin{array}{c}\text { Penetration Level } \\
(\%)\end{array}$ & $\begin{array}{c}\text { Bus Voltages } \\
\text { (p.u.) }\end{array}$ \\
\hline T1 & 20 & 1.01 \\
T2 & 40 & 1.03 \\
T3 & 60 & 1.07 \\
T4 & 80 & 1.11 \\
T5 & 100 & 1.13 \\
\hline
\end{tabular}

\section{3,2 Voltage Mitigation Method using BESS}

From the simulation with BESS, the DC-DC buck boost converter is able to regulate the voltage output to 400 $\mathrm{V}_{\text {rms }} V_{r m s}$ with voltage ripple, $\Delta \mathrm{V}_{\circ}$ of less than $1 \%$ as shown in Figure 12.

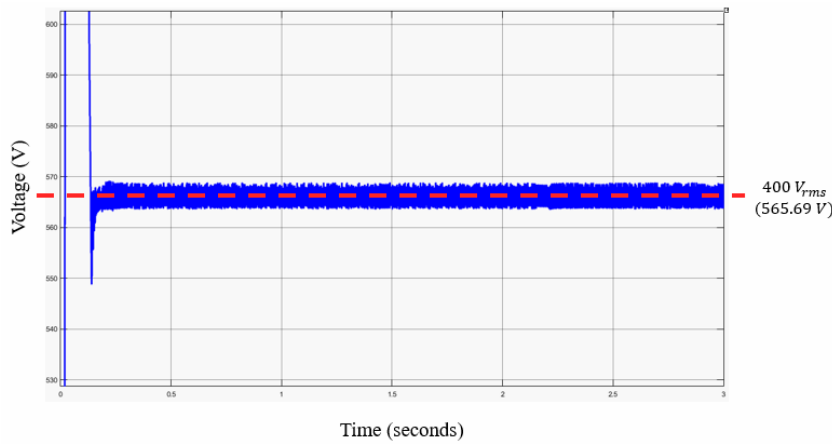

Figure 12 Output voltage of the buck/boost converter

From Figure 13, it is shown that at $\mathrm{T} 4(80 \%)$ and T5 $(100 \%)$ in which the voltage violation occurred, the BESS successfully regulates the voltage levels to 1.01 p.u. The values of bus voltage levels after regulation are tabulated in Table 2.

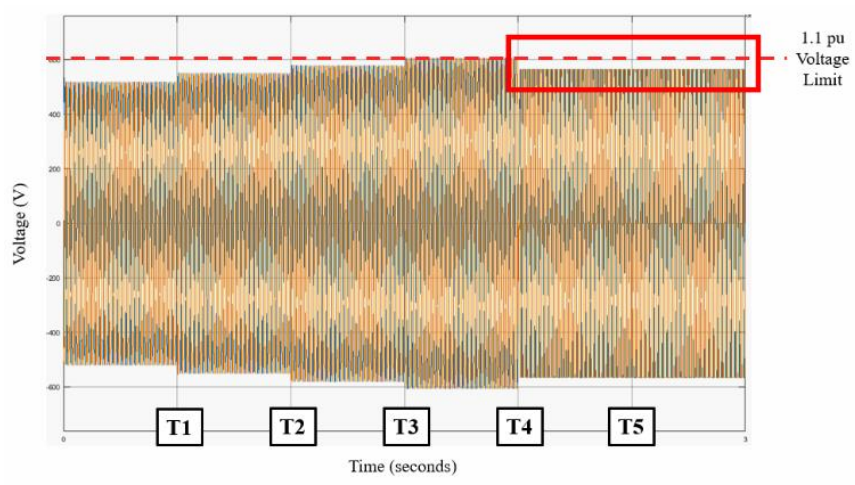

Figure 13 Bus voltage level after BESS implemented
When voltage rise occurred at T4 and T5, the battery activated the charge MODE of operation control as the BESS detected voltage at PCC to be higher than 1.1 p.U. The converter controller now proceeded to compare the voltage level with reference voltage and thus operated in buck mode. During buck mode, the bi-directional converter sends current from the distribution system to the battery. From Figure 14, the current level increased at T4 and T5 which essentially means charging occurred at that particular time respectively.
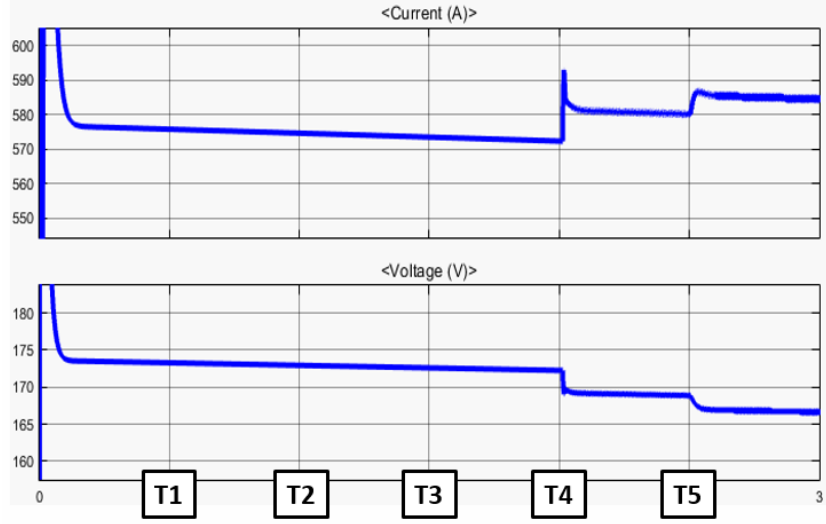

Figure 14 Current and voltage level of battery

Table 2 Bus Voltages at 20\%, 40\%, 60\%, 80\%, 100\% PV Penetration from Before and After BESS is Implemented

\begin{tabular}{cccc}
\hline Time & $\begin{array}{c}\text { Penetration } \\
\text { level (\%) }\end{array}$ & $\begin{array}{c}\text { Bus Voltages } \\
\text { Before } \\
\text { Implementing } \\
\text { BESS (p.u.) }\end{array}$ & $\begin{array}{c}\text { Bus Voltages } \\
\text { After } \\
\text { Implementing } \\
\text { BESS (p.u.) }\end{array}$ \\
\hline T1 & 20 & 1.01 & 1.01 \\
T2 & 40 & 1.03 & 1.03 \\
T3 & 60 & 1.07 & 1.07 \\
T4 & 80 & 1.11 & 1.01 \\
T5 & 100 & 1.13 & 1.01 \\
\hline
\end{tabular}

\subsection{CONCLUSION}

This paper highlights the ability of a BESS to overcome voltage rise problem in the distribution system especially during high PV penetration. Comparative study of voltage profiles at the point of common coupling is done before and after the application of BESS. From the simulation study without implementing BESS, it is found that during the low load and peak generation conditions, voltage rise of 1.11 p.u. and 1.13 p.u. occurred at high penetration level of $80 \%$ and $100 \%$ respectively as PV penetration level increases. Then, the proposed BESS system with $400 \mathrm{~V} / 240 \mathrm{~V}$ bidirectional DC-DC buck-boost converter is connected to the simplified distribution system. The result shows that it is able to regulate the voltage violation to the 
voltage level of 1.01 p.u, which is comply with the standard limit range.

\section{Acknowledgement}

This research is fully supported by university grant, GUP (Tier 2) with reference and cost numbers are PY/2019/00367 and Q.J130000.2651.17J06, respectively. The authors fully acknowledged Ministry of Higher Education (MOHE) and Universiti Teknologi Malaysia for the approved fund which makes this important research viable and effective.

\section{References}

[1] T. Olowu, A. Sundararajan, M. Moghaddami, A. Sarwat. 2018. Future Challenges and Mitigation Methods for High Photovoltaic Penetration: A Survey. Energies. 11(7): 1782. DOI: https://doi.org/10.3390/en1 1071782.

[2] M. Nouha, A. lashab, D. Sera, J. M. Guerrero. 2019. Large Photovoltaic Power Plants Integration: A review of Challenges and Solutions. Energies. 12(19): 3798. DOI: 10.3390/en12193798.

[3] A. A. Solomon. 2019. Large Scale Photovoltaic and the Future Energy Requirement. AIMS Energy. 7(5): 600-618. Doi: 10.3934/energy.2019.5.600.

[4] International Renewable Energy Agency. 2019. Data and Statistics-IRENA Resource; International Renewable Energy Agency: Abu Dhabi, UAE.

[5] J. von Appen, M. Braun, T. Stetz, K. Diwold and D. Geibel. 2013. Time in the Sun: The Challenge of High PV Penetration in the German Electric Grid. IEEE Power and Energy Magazine. 11 (2): 55-64. DOI: 10.1109/MPE.2012.2234407.

[6] T. Stetz, F. Marten, M. Braun. 2012. Improved Low Voltage Grid-integration of Photovoltaic Systems in Germany. IEEE Transactions on Sustainable Energy. 4(2): 534-542. DOI:10.1109/TSTE.2012.2198925.

[7] M. Braun, T. Stetz, R. Brundlinger, C. Mayr. 2012. Is the Distribution Grid Ready to Accept Large Scale Photovoltaic Deployment? State of the Art, Progress, and Future Prospects. Progress in Photovoltaic Research and Applications. 20(6). DOI: 10.1002/pip.1204.

[8] Y. Hishikawa, H. Tobita, A. Sasaki, K. Yamagoe, T. Onuma and Y. Tsuno. 2013. Current-voltage Characteristics of Novel PV Devices under Various Irradiance and Temperature Conditions. IEEE 39th Photovoltaic Specialists Conference (PVSC). 1417-1422. DOI: 10.1109/PVSC.2013.6744409.

[9] Y. Ueda, Y. Tsuno, M. Kudou, H. Konishi, K. Kurokawa. 2010. Comparison between the I-V Measurement and the System Performance in Various Kinds of PV Technologies. Proceedings of the 25th EUPVSEC / 5th WCPEC (2010) Valencia, Spain. 3735-3739. DOI:10.4229/25thEUPVSEC2010-4EP.1.5.

[10] Y. Tsuno, Y. Hishikawa, K. Kurokawa. 2006. Translation Equations for Temperature and Irradiance of the I-V Curves of the Various PV Cells and Modules. 2006 IEEE 4th World Conference on Photovoltaic Energy Conference. DOI: 10.1109/WCPEC.2006.279619.

[11] Distribution Code for Peninsular Malaysia, Sabah \& F.T. Labuan (Amendments) 2017 (KOD/ST/NO.1/2016(pin.2017).

[12] A. P. Kenneth and K. Folly. 2014. Voltage Rise Issue with High Penetration of Grid Connected PV. International
Federation of Automatic Control. 47(3): 4959-4966. DOI: https://doi.org/10.3182/20140824-6-ZA-1003.01989.

[13] S. Ali, N. Pearsall, G. Pulrus. 2012. Impact of High Penetration Level of Grid-connected Photovoltaic System on UK Low Voltage Distribution Network. Renewable Energy and Power Quality Journal. 1(10): 519-522. DOI: 10.24084/REPQJ10.368.

[14] C. Gonzalez, et al. 2012. LV Distribution Network Feeders in Belgium and Power Quality Issues Due to Increasing PV Penetration Levels. 2012 3rd IEEE PES Innovative Smart Grid Technologies Europe (ISGT Europe). 1-8. Doi: 10.1109/ISGTEurope.2012.6465624.

[15] X. Liu, A. Aichhorn, L. Liu and H. Li. 2012. Coordinated Control of Distributed Energy Storage System with Tap Changer Transformers for Voltage Rise Mitigation Under High Photovoltaic Penetration. IEEE Transactions on Smart Grid. 3(2): 897-906. DOI: 10.1109/TSG.2011.2177501.

[16] P. Carvalho, P. Correia, L. Ferreira. 2008. Distributed Reactive Power Generation Control for Voltage Rise Mitigation in Distribution Networks. IEEE Transaction on Power System. 23(2): 766-772. Doi: 10.1 109/TPWRS.2008.919203.

[17] M. Hojo, H. Hatano and Y. Huwa. 2009. Voltage Rise Suppression by Reactive Power Control with Cooperating Photovoltaic Generation Systems. Proc. 20th CIRED Int. Conf. Electr. Distrib. 1-4. DOI:10.1049/cp.2009.0667.

[18] H. Yang, Y. Chen, J. Liao and C. Yang. 2015. Over-voltage Mitigation Control Strategies for Distribution System with High PV Penetration. International Conference on Intelligent System Application to Power Systems (ISAP). 1-6. DOI: 10.1109/ISAP.2015.7325529.

[19] J. F. Gómez-Gonzále, D. Cañadillas-Ramall, B. GonzálezDía, J. A. Méndez-Pérez, J. Rodríguez, J. Sánchez and R. Guerrero-Lemus. 2018. Reactive Power Management in Photovoltaic Installations Connected to Low-voltage Grids to Avoid Active Power Curtailment. International Conference on Renewable Energies and Power Quality. 16. DOI:10.24084/repaj16.003.

[20] E. Demirok, P. C. González, K. H. B. Frederiksen, D. Sera, P. Rodriguez and R. Teodorescu. 201 1. Local Reactive Power Control Methods for Overvoltage Prevention of Distributed Solar Inverters in Low-voltage Grids. IEEE Journal of Photovoltaics. 1(2): 174-182. Doi: 10.1109/JPHOTOV.2011.2174821.

[21] D. lioka, T. Fujii, T. Tanaka 2, T. Harimoto 2 and J. Motoyama. 2020. Voltage Reduction in Medium Voltage Distribution Systems Using Constant Power Factor Control of PV PCS. Energies. 13(5430): 1-17. Doi:10.3390/en13205430.

[22] M. Maharjan, U. Tamrakar, Z. Ni, B. Bhattarai and R. Tonkoski. 2021. Overvoltage Prevention and Curtailment Reduction Using Adaptive Droop-based Supplementary Control in Smart Inverters. Applied Science. 11(17): 7900. https://doi.org/10.3390/app11177900.

[23] Z. Zhanga, C. Dou, D.Yue, B. Zhang, P. Zhao. 2021. Higheconomic PV Power Compensation Algorithm to Mitigate Voltage Rise with Minimal Curtailment. International Journal of Electrical Power \& Energy Systems. 125. https://doi.org/10.1016/j.ijepes.2020.106401.

[24] D. H. C Lam, J. Wong, Y. S. Lim, J. C. Y. Hee. 2019. DSTATCOM-Fuel Cell System on Radial Low-voltage Distribution Network for Mitigating Voltage Rise Caused by High Penetration of Photovoltaic Systems. Advances in Science, Technology and Engineering Systems Journal. 4(4): 285-291. DOI: 10.25046/aj040436.

[25] N. Jenkins, J. B. Ekanayake and G. Strbac. 2010. Distributed Generation. The Institution of Engineering and Technology, London, United Kingdom. 